\title{
EFFECTS OF THE INCREASE IN SUBSTRATE LOAD AND HYDROLYSIS TIME IN THE SACCHARIFICATION OF SUGARCANE BAGASSE AND ETHANOL PRODUCTION
}

\author{
K. F. LAMOUNIER ${ }^{1}$, P. O. RODRIGUES ${ }^{2}$, D. PASQUINI ${ }^{3}$, A. S. SANTOS ${ }^{4}$, M. A. BAFFI ${ }^{5}$ \\ Universidade Federal de Uberlândia ${ }^{1,2,3,5}$, Universidade Federal dos Vales do Jequitinhonha e Mucuri ${ }^{4}$ \\ ORCID ID: https://orcid.org/0000-0003-2536-9288 ${ }^{1}$ \\ kkeninhala@yahoo.com.br ${ }^{1}$
}

Submetido 31/01/2020 - Aceito 16/10/2020

DOI: $10.15628 /$ holos.2020.9485

\begin{abstract}
In this study, the enzymatic saccharification of alkaline pretreated sugarcane bagasse (PSB) and the production of second generation bioethanol $(2 \mathrm{G})$ were investigated. The effects of percentage of dry substrate ( 3 and $10 \%$ $\mathrm{w} / \mathrm{v}$ ) and time of hydrolysis ( 24 and $72 \mathrm{~h}$ ) were evaluated in order to obtain maximum contents of total reducing sugar (TRS), glucose and xylose. The monosaccharide concentrations were quantified by High Performance Liquid Chromatography (HPLC) and TRS by the 3.5dinitrosalicylic acid (DNS) method. The saccharification of PSB with the Cellic Ctec3 promoted an efficient release of sugars. Among the four evaluated conditions, the hydrolysis HD (10\% PSB and $72 \mathrm{~h}$ ) was the most efficient with the highest production of sugars (g/L): TRS (73.96),
\end{abstract}

glucose (31.78) and xylose (10.85). The alcoholic fermentation of hydrolysate HD produced the maximum concentration of $16.15 \mathrm{~g} / \mathrm{L}$ of ethanol, with volumetric productivity $\left(Q_{P}\right)$ of $0.69 \mathrm{~g} / \mathrm{Lh}$ and yield of ethanol as a function of the substrate $\left(\mathrm{Y}_{\mathrm{P} / \mathrm{S}}\right)$ of $0.48 \mathrm{~g}_{\text {ethanol }} / \mathrm{g}_{\text {sugar. }} \mathrm{S}$. cerevisiae was capable of fermenting $99.96 \%$ of glucose from hydrolysate HD. The results indicated that the increase of the substrate load and time in the enzymatic hydrolysis can be favorable alternatives to improve the sugar yields and, consequently, the bioethanol production.

KEYWORDS: sugarcane bagasse, enzymatic hydrolysis, substrate load, fermentation, bioethanol.

\section{EFEITOS DO AUMENTO DA CARGA DO SUBSTRATO E DO TEMPO DE HIDRÓLISE NA SACARIFICAÇÃO DE BAGAÇO DE CANA-DE-AÇÚCAR E PRODUÇÃO DE ETANOL}

\section{RESUMO}

Neste estudo, a sacarificação enzimática do bagaço de cana-de-açúcar submetido a pré-tratamento alcalino (PSB) e a produção de bioetanol de segunda geração (2G) foram investigadas sob diferentes condições. Os efeitos da percentagem de substrato seco ( 3 e $10 \% \mathrm{~m} / \mathrm{v}$ ) e tempo de hidrólise ( 24 e $72 \mathrm{~h}$ ) foram avaliados a fim de obter teores máximos de açúcares redutores totais (ART), glicose e xilose. As concentrações de monossacarídeos foram quantificadas por Cromatografia Líquida de Alta Eficiência (CLAE) e os açúcares redutores pelo método do ácido 3,5-dinitrosalicílico (DNS). A sacarificação do bagaço com a enzima comercial Cellic Ctec3 promoveu uma liberação eficiente de açúcares. Entre as quatro condições avaliadas, a hidrólise HD ((10\% PSB e $72 \mathrm{~h})$ foi a mais eficiente com a maior produção de açúcares $(\mathrm{g} / \mathrm{L})$ : ART $(73,96)$, glicose $(31,78)$ e xilose $(10,85)$. A fermentação alcoólica do hidrolisado HD produziu concentração máxima de $16,15 \mathrm{~g} / \mathrm{L}$ de etanol, com produtividade volumétrica $\left(Q_{p}\right)$ de $0,69 \mathrm{~g} / \mathrm{Lh}$ e rendimento de etanol em função do substrato $\left(\mathrm{Y}_{P / S}\right)$ de $0,48 \mathrm{~g}$ de etanol/g de açúcar. S. cerevisiae foi capaz de fermentar $99,96 \%$ da glicose a partir do hidrolisado HD. Os resultados indicaram que o aumento da carga de substrato e tempo na hidrólise enzimática podem ser alternativas favoráveis para melhorar o rendimento em açúcares e, consequentemente, a produção de bioetanol.

PALAVRAS-CHAVE: bagaço de cana, hidrólise enzimática, carga de substrato, fermentação, bioetanol.

HOLOS, Ano 36, v.6, e9485, 2020 


\section{INTRODUCTION}

The search for renewable energy sources has increased in the last decades due to rising energy demand, the consequent indiscriminate use of fossil fuels and the intensification of the greenhouse gas emissions (Antil, Gupta, \& Kuhad, 2014). Thus, the energy security and the climate changes require the large scale substitution of petroleum-based fuels by biofuels (Pathania, Sharma, \& Handa, 2017). Among the potential alternatives, the development of biofuels from lignocellulose residues, such as second-generation bioethanol ( $2 \mathrm{G}$ ethanol), has been considered a promising choice due to its carbon-balanced properties and its ability to decrease the dependence on fossil fuels or replace them entirely (Guerrero, Ballesteros, \& Ballesteros, 2018; Petrou \& Pappis, 2009). Besides, 2 G bioethanol can contribute to the reduction of environmental problems, such as deforestation for the creation of new planting zones and the consequent increase in greenhouse gas emissions.

Agroindustry produces tones of lignocellulose residues (LC) that can be reused for the production of $2 \mathrm{G}$ bioethanol. Lignocellulose biomass, such as sugarcane bagasse (SCB), are attractive feedstock with wide availability and low-cost (Nouri, Azin, \& Mousavi, 2017). SCB, the major by-product of the sugarcane industry, is economically viable and promising for application in the production of bioethanol (Wanderley, Martín, Rocha, \& Gouveia, 2013). For the bioconversion of LC to bioethanol, it is necessary to rupture and disorganize the lignocellulose fiber and to depolymerize the target polysaccharides into their component monosaccharides. This can be achieved through three steps: pre-treatment of biomass, enzymatic hydrolysis, and alcoholic fermentation by yeasts (Rodrigues et al., 2017; Wanderley et al., 2013).

Nonetheless, the recalcitrance of biomass, due to many physico-chemical, structural and compositional factors, limits its efficient enzymatic conversion to fermentable sugars. Thus, a pretreatment step is necessary in order to remove lignin, increase the porosity of the material, reduce the crystallinity of the cellulose, and improve its digestibility in the next saccharification stage (Valinhas et al., 2018). Chemical pre-treatments, such as alkaline pre-treatment with sodium hydroxide $(\mathrm{NaOH})$, may facilitate the attack of hydrolytic enzymes on the biomass to unlock the structure of lignocellulose and reduce the amount of enzyme required during hydrolysis (Antil et al., 2014).

Enzymatic hydrolysis represents an ecologically friendly method for the release of fermentable sugars from biomass using a multicomponent enzyme system composed by cellulases and hemicellulases (Rodrigues et al., 2017). This process has many advantages, including low energy requirements, no corrosion problems, less by-product formation, improved sugar yields and it can run under mild environmental conditions (Saratale, Saratale, Kim, \& Kumar, 2018). Saccharification of LC can be carried out directly using commercial multi-enzyme cocktails, which normally result in rapid hydrolysis rates and high sugar liberation (Saratale et al., 2018). However, some factors can affect the efficiency of hydrolysis such as percentage of substrate, substrate load, temperature, $\mathrm{pH}$, and time of hydrolysis. Therefore, the optimization of these conditions is crucial 
to enhance enzymatic saccharification, improve sugar yield and, consequently, increase bioethanol production (Antil et al., 2014).

Fermentations of the monosaccharides released in the enzymatic hydrolysates can be carried out by the conventional yeast Saccharomyces cerevisiae. It has several benefits in the production of bioethanol: high fermentation capacity of glucose, adaptation to industrial processes and high tolerance to ethanol and inhibitors (Martín, Galbe, Wahlbom, Hahn-Hägerdal, \& Jönsson, 2002). In this context, the present study investigated the saccharification conditions of sugarcane bagasse previously submitted to alkaline pre-treatment (PSB), in order to enhance the yield of sugars. The percentage of PSB (solid load) in the reaction mixture and the time of enzymatic hydrolysis were evaluated in order to promote high monosaccharide release and consequent bioethanol production from the hydrolysates.

\section{MATERIALS E METHODS}

\subsection{Sugarcane bagasse and chemicals}

Sugarcane bagasse previously pre-treated with $2 \% \mathrm{NaOH}$ solution (PSB) at $100{ }^{\circ} \mathrm{C}$ for $4 \mathrm{~h}$ was kindly donated from Ms. P.O. Rodrigues (Uberlandia Federal University, Brazil). PSB, composed of $10.94 \%$ of total lignin, $55.11 \%$ of cellulose, and $9.24 \%$ of hemicellulose (Rodrigues et al., 2017), was stored at room temperature free of moisture until its use in enzymatic saccharification. The reagent 3.5-Dinitrosalicylic acid (DNS) was purchased from Sigma. Other chemicals and media components were purchased locally.

\subsection{Enzymatic hydrolysis}

The PSB samples (pre-moistened for $24 \mathrm{~h}$ in distilled water) were enzymatically hydrolyzed in $50 \mathrm{~mL}$ Erlenmeyer flasks, sealed with latex closures, containing $10 \mathrm{FPU} / \mathrm{g}$ of cellulose (dry basis) of Cellic Ctec3 enzymatic cocktail (Novozymes) and sodium citrate buffer $(0.1 \mathrm{~mol} / \mathrm{L}, \mathrm{pH} 4.8)$, shaken at $150 \mathrm{rpm}$ at $50{ }^{\circ} \mathrm{C}$ in a final volume of $25 \mathrm{~mL}$. The activity of Cellic Ctec 3 was quantified with filter paper tape ( $1 \mathrm{~cm}$ wide by $6 \mathrm{~cm}$ long) as a substrate and expressed as filter paper units (FPU) per $\mathrm{mL}$ of enzymatic preparation (Ghose, 1987). In order to optimize the saccharification, two parameters (percentage of PSB in the reaction mixture and the time of hydrolysis) were evaluated in four conditions: HA - $3 \%$ PSB w/v during $24 \mathrm{~h}$; HB - 3\% PSB w/v during $72 \mathrm{~h}, \mathrm{HC}-10 \%$ PSB w/v during $24 \mathrm{~h}$ and HD- 10\% PSB w/v during $72 \mathrm{~h}$. The hydrolysates were filtered through a $0.22 \mu \mathrm{m}$ membrane, centrifuged at 10,000 rpm for $30 \mathrm{~min}$ and the supernatants were analyzed for further quantification of sugars and inhibitory compounds.

TRS in the filtrates were quantified by the DNS method at $540 \mathrm{~nm}$ using a glucose analytical curve as a reference (Miller, 1959). The concentrations of glucose, xylose, arabinose, cellobiose, organic acids (oxalic, formic, acetic and galacturonic), furfural (FF) and 5-hydroxymethylfurfural (HMF) released after hydrolysis were quantified by HPLC. The hydrolysates were diluted with the mobile phase $\left(0.1 \%(\mathrm{v} / \mathrm{v})\right.$ aqueous phosphoric acid $\left.-\mathrm{H}_{3} \mathrm{PO}_{4}\right)$, membrane filtered $(0.20 \mu \mathrm{m}$ pore size, Chromafil Xtra CA-20/25) and injected into the chromatographic system (Shimadzu ${ }^{\mathrm{TM}}$ model LC- 
20A Prominence), equipped with a Supelcogel TM C- $610 \mathrm{H}$ column at $32^{\circ} \mathrm{C}$, isocratic elution at 0.5 $\mathrm{mL} / \mathrm{min}$ and ultraviolet (operating at a wavelength of $210 \mathrm{~nm}$ ) and refractive index detectors (Moreira et al., 2017). Glucose, xylose, arabinose, cellobiose, organic acids, FF, and HMF standards were used. All assays were performed in triplicate.

\subsection{Alcoholic fermentation of hydrolysates}

To obtain the pre-inoculum, S. cerevisiae ( ${ }^{\circledR}$ Fleischmann) was grown in YEPD liquid medium (composed of $10 \mathrm{~g} / \mathrm{L}$ of yeast extract, $20 \mathrm{~g} / \mathrm{L}$ of peptone, and $20 \mathrm{~g} / \mathrm{L}$ of D-glucose) at $28 \pm 2^{\circ} \mathrm{C}$ by orbital shaking at $130 \mathrm{rpm}$ under two conditions. In the first condition, the yeast cells were cultivated in the inoculation medium until they reached an optical density (O.D.) of 1.0 at $600 \mathrm{~nm}$. In the second condition, yeast cells were cultured for $24 \mathrm{~h}$. After microbial growth, culture media were centrifuged at 5,000 rpm for $30 \mathrm{~min}$ and the supernatants were discarded. The cells were then washed with sterile distilled water, centrifuged to remove the residue from the culture medium and suspended in sterile distilled water to the original medium volume. Pre-inocula were employed in alcoholic fermentation in the proportion of $10 \%(\mathrm{v} / \mathrm{v})($ Brito et al., 2017). Alcoholic fermentations were performed at $28 \pm 2^{\circ} \mathrm{C}$ for $72 \mathrm{~h}$ in $50 \mathrm{~mL}$ Erlenmeyer flasks containing $9 \mathrm{~mL}$ of filtrate hydrolysates and $1 \mathrm{~mL}$ of pre-inoculum (1.0 OD or $24 \mathrm{~h}$ growth), without agitation.

Hydrolysates samples containing fermentable monosaccharides were assayed for sugar consumption and ethanol production. The fermentation samples were centrifuged at $10,000 \mathrm{rpm}$ for $10 \mathrm{~min}$, the supernatants were filtered $(0.22 \mu \mathrm{m})$ for ethanol quantification and analysed by HPLC for sugar consumption and ethanol/organic acids production, using standard commercial grade reagents (Moreira et al., 2017). The pellets were used to evaluate the cell viability (CV) of the fermentations.

The fermentative characteristics: $C V$, sugar consumption $(\mathrm{g} / \mathrm{L})$, ethanol content $(\mathrm{g} / \mathrm{L})$, ethanol yield as function of the substrate $\left(Y_{p / s}\right)$, and volumetric productivity $\left(Q_{p}\right)$ were analyzed every $24 \mathrm{~h}$ (Brito et al., 2017). CV was evaluated in two conditions: in the first one, hydrolysates HA and HD were used as fermentative culture medium. After the selection of the best culture medium, pre-inocula of $24 \mathrm{~h}$ or $1.0 \mathrm{OD}$ (supplemented with the model solution; but without addition of glucose and xylose) were investigated for CV. The viable cells were counted using an optical microscope with a Neubauer ${ }^{\circledR}$ cell counting chamber using methylene blue dye, wherein the viable cells were observed as colourless and the non-viable cells were stained of blue. CV was expressed in number of cells $/ \mathrm{mL}$ in the equation 1 :

$$
C V(\mathrm{cell} / m L)=\left(\frac{n \times d_{f}}{0.004}\right) \times 1000
$$

Where: $\mathrm{n}=$ number of 5 counts; $\mathrm{df}=$ dilution factor; $1,000=$ conversion factor from $\mathrm{mm}^{3}$ to $\mathrm{cm}^{3} ; 0.004=$ volume of the square where the counting was performed.

The ethanol yield $\left(\mathrm{Y}_{\mathrm{P} / \mathrm{s}}, \mathrm{g}_{\text {ethanol }} / \mathrm{g}_{\text {sugar }}\right)$ was measured based on the ratio between the ethanol produced and the sugars consumed. The volumetric productivity $\left(Q_{p}, g / L h\right)$ was calculated based on the maximum concentration of ethanol and its corresponding fermentation time (Brito et al., 
2017). All of the experiments were performed in triplicate and the results were presented as the mean \pm standard deviation.

\section{RESULTS E DISCUSSION}

\subsection{Enzymatic hydrolysis}

The major challenges of an efficient enzymatic hydrolysis of the lignocellulose biomass are the cellulose crystallinity, the removal of lignin content, the hemicelluloses distribution and the particle size (Wanderley et al., 2013). These factors represent restrictions to enzyme accessibility and to the release of fermentable sugars from polysaccharide depolymerization. Chemical pretreatments, such as alkaline treatment with $\mathrm{NaOH}$, can promote swelling, decrease the degree of polymerization, reduce crystallinity and delignification in order to improve the enzymatic conversion of cellulose (Wanderley et al., 2013). In our study, alkaline pre-treated sugarcane bagasse (PSB) with a reduced lignin content was examined for enzymatic hydrolysis and release of fermentable sugars. Among the four investigated conditions, the hydrolysis HD, performed with $10 \%$ PSB during $72 \mathrm{~h}$, was the most efficient in the liberation of sugars, producing the highest TRS concentration $(71.00 \mathrm{~g} / \mathrm{L})$ in comparison to the other hydrolysates (Table 1$)$. These results indicated that the increase of the dry substrate percentage was the decisive factor that improved the effectiveness of the hydrolysis and the liberation of sugars. On the other hand, the time of hydrolysis was not an important factor for the improvement of the enzymatic process, with nonsignificant differences in the values of TRS among the experiments developing within 24 and $72 \mathrm{~h}$ (Table 1).

Similar improvement in the amount of liberated reducing sugars was observed by Rodrigues et al. (2017) after an enzymatic hydrolysis carried out with increased SCB percentage, suggesting that high solid loading can improve saccharification yields. In all the enzymatic assays, the production of TRS was noteworthy in comparison to earlier studies Huang et al. (2016) obtained $20.20 \mathrm{~g} / \mathrm{L}$ of TRS after an enzymatic hydrolysis of $3 \%$ of sodium ethoxide pre-treated SCB using the commercial cocktails Celluclast $1.5 \mathrm{~L}$ and Novozymes 188 ( $1 \mathrm{FPU} / 4 \rho \mathrm{NPGU})$ at $45^{\circ} \mathrm{C}$, for $72 \mathrm{~h}$. Silva et al. (2017) achieved about $16.00 \mathrm{~g} / \mathrm{L}$ of TRS after the hydrolysis in similar conditions to the present study (3\% of SCB pre-treated with steam blast and $\mathrm{NaOH}, 10 \mathrm{FPU} / \mathrm{g}$ of cellulose of Cellic Ctec3, at $50{ }^{\circ} \mathrm{C}$ for $24 \mathrm{~h}$ ). Interestingly, these authors also carried out enzymatic hydrolysis for $72 \mathrm{~h}$ at the same conditions and obtained $23.05 \mathrm{~g} / \mathrm{L}$ of TRS, indicating that an increase in the hydrolysis time positively affected TRS release. (de Sousa Gomes et al., 2017) obtained $5.0 \mathrm{~g} / \mathrm{L}$ of TRS from the saccharification of $2 \%$ of alkaline pre-treated SCB with the enzymatic cocktail Multifect ${ }^{\circledR} \mathrm{CL}$ (10 $\mathrm{FPU} / \mathrm{g}$, at $50^{\circ} \mathrm{C}$ and $72 \mathrm{~h}$ ).

The production of high concentrations of monosaccharides after hydrolysis is essential to achieve worthy ethanol yields in the fermentation stage. To efficiently hydrolyze the sugarcane bagasse biomass, it is necessary to find the maximum solid load of substrate (Raj and Krishnan, 2019). Hence, when the PSB percentage was increased from 3 to 10\%, the yield of released sugars increased, with the highest concentrations of glucose $(31.78 \mathrm{~g} / \mathrm{L})$ and xylose $(10.75 \mathrm{~g} / \mathrm{L})$ also obtained after hydrolysis HD carried out with $10 \%$ PSB during $72 \mathrm{~h}$ (Table 1 ). These results indicated 
the increase in the solid load in enzymatic hydrolysis clearly favored the greatest sugar release observed in hydrolysis HD. It was also observed that the xylose concentration also improved with the increase of the hydrolysis time (Table 1). On the other hand, the lowest concentrations of glucose $(10.77 \mathrm{~g} / \mathrm{L}$ ) and xylose $(4.96 \mathrm{~g} / \mathrm{L})$ were achieved after hydrolysis HA performed with $3 \%$ PSB during $24 \mathrm{~h}$, similarly demonstrating that the percentage of substrate and the time are decisive factors for the accomplishment of the process of saccharification (Table 1). Thus, hydrolysate HD was selected as the most suitable material for the following stage of alcoholic fermentation and hydrolysate HA was also fermented for comparison.

The glucose and xylose recovery in hydrolysates were higher than those found by Pereira, Travaini, Paganini Marques, Bolado-Rodríguez, \& Bocchini Martins, (2016), who reported $4.13 \mathrm{~g} / \mathrm{L}$ of glucose and $1.08 \mathrm{~g} / \mathrm{L}$ of xylose, from the hydrolysis of ozonolysis pre-treated SCB with Celluclast $1.5 \mathrm{~L}$ and Novozym 188 (10 FPU/30 CBU/g cellulose). Nascimento et al. (2016) observed a similar glucose concentration $(38.8 \mathrm{~g} / \mathrm{L})$ after enzymatic hydrolysis at the same conditions of percentage of PSB, time and temperature, but these authors employed double the enzymatic load (Accelerase 1500, $20 \mathrm{FPU} / \mathrm{g}$ of cellulose). The released glucose concentration after hydrolysis HD was equivalent to the study of Wanderley et al. (2013), in which the greatest glucose concentration (39 $\mathrm{g} / \mathrm{L}$ ) was achieved in the batch enzymatic hydrolysis of delignified SCB using $10 \mathrm{FPU} / \mathrm{g}$ cellulose of Celluclast $1.5 \mathrm{~L}$ and Trichoderma reesei $\beta$-glucosidase (Novozymes) at $50^{\circ} \mathrm{C}$ during $120 \mathrm{~h}$. (de Andrade et al., 2017) performed a saccharification of $2 \%$ of alkaline pre-treated SCB with the enzymatic cocktail Multifect ${ }^{\circledR} \mathrm{CL}$ supplemented with $\beta$-glucosidases from Chrysoporthe cubensis at similar conditions of enzymatic load, temperature, time and agitation and produced lower monosaccharide concentration ( $2.82 \mathrm{~g} / \mathrm{L}$ of glucose and $0.98 \mathrm{~g} / \mathrm{L}$ of xylose) than the present study. Jiang et al. (2017) also obtained lower concentrations of TRS (33.8 g/L) and glucose $(20.9 \mathrm{~g} / \mathrm{L})$ after enzymatic hydrolysis of $\mathrm{Na}_{2} \mathrm{SO}_{3} / \mathrm{Na}_{3} \mathrm{PO}_{4}$ pre-treated $\mathrm{SCB}$ with complexed enzymes (15 FPU/g and $60 \mathrm{CBU} / \mathrm{g} \mathrm{SCB}$ ). Comparing the achieved TRS, glucose and xylose yields to previous reports using the same conditions, it was concluded that the hydrolysis HD obtained significant quantities of released sugars and this hydrolysate was submitted to alcoholic fermentation as a fermentable sugar source.

Overall, the presence of toxic by-products HMF and FF was not observed in any hydrolysate sample. HMF and FF can have inhibitory effects on the growth of yeast during the fermentative process, thereby offering low bioethanol yields (Sahu \& Pramanik, 2018). Thus, the results demonstrated that alkaline pre-treated sugarcane bagasse could be efficiently saccharified by the Cellic Ctec 3 cocktail without the generation of compounds inhibitory to the next fermentative step.

Table 1: Compounds released after PSB saccharification with Cellic Ctec3 multi-enzyme complex.

\begin{tabular}{c|c|c|c|c}
\hline \multirow{2}{*}{$\begin{array}{c}\text { Compounds } \\
\text { (g/L) }\end{array}$} & $\mathrm{HA}^{\mathrm{a}}$ & $\mathrm{HB}^{\mathrm{b}}$ & $\mathrm{HC}^{\mathrm{c}}$ & $\mathrm{HD}^{\mathrm{d}}$ \\
\cline { 2 - 5 } & $43.25 \pm 0.83$ & $43.80 \pm 0.68$ & $71.00 \pm 0.35$ & $73.96 \pm 0.36$ \\
TRS & $10.77 \pm 0.27$ & $10.85 \pm 0.84$ & $15.95 \pm 0.89$ & $31.78 \pm 2.56$ \\
Glucose & $4.96 \pm 0.07$ & $5.13 \pm 0.51$ & $6.70 \pm 0.87$ & $10.85 \pm 1.00$ \\
Xylose & \multicolumn{4}{|c}{} \\
\hline
\end{tabular}

HOLOS, Ano 36, v.6, e9485, 2020 


\begin{tabular}{|l|l|l|l|l|} 
Cellobiose & $\mathrm{ND}^{f}$ & $0.11 \pm 0.08$ & $1.62 \pm 0.31$ & $1.68 \pm 1.13$ \\
\hline
\end{tabular}

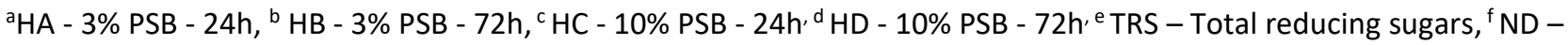
below the limit of detection.

\subsection{Cell Viability}

Figures $1 \mathrm{~A}$ and $1 \mathrm{~B}$ present the $\mathrm{CV}$ during the fermentative process was studied using $S$. cerevisiae. The alcoholic fermentation of hydrolysate HD (10\% of PSB - $72 \mathrm{~h}$ ) exhibited higher CV $\left(5.35 \times 10^{9}\right.$ cells $\left./ \mathrm{mL}\right)$ than the fermentation of hydrolysate HA due to its higher concentration of sugars (Table 1). Thus, the fermentation carried out with hydrolysate HD was selected as the best condition for cell viability (Figure 1A). After the selection of the best substrate for yeast growth (hydrolysate HD), the fermentations with pre-inocula prepared by inoculating a loop full of $24 \mathrm{~h}$ old yeast culture or yeast culture grew up to $1.0 \mathrm{OD}$ at $600 \mathrm{~nm}$ were performed to evaluate cell viability. According to Figure $1 \mathrm{~B}, \mathrm{~S}$. cerevisiae exhibited enhanced CV in the fermentation carried out with 24 h-old pre-inoculum $\left(7.76 \times 10^{9}\right.$ cells $\left./ \mathrm{mL}\right)$.
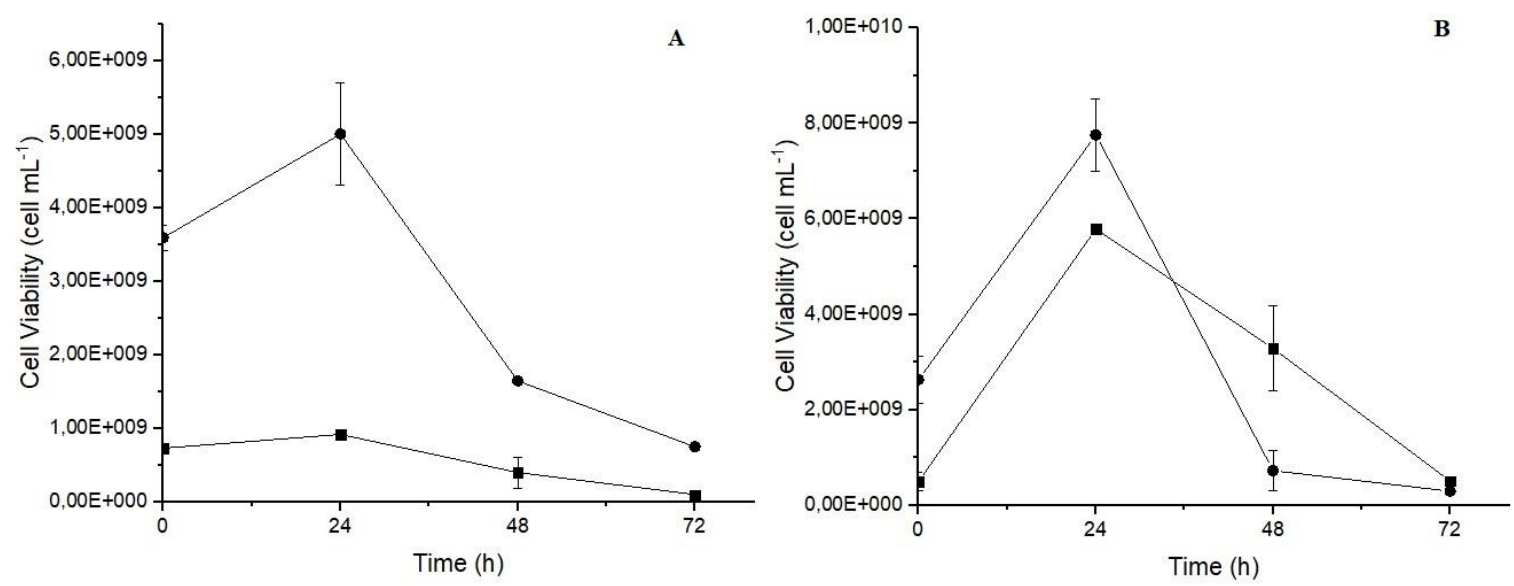

Figure 1: S. cerevisiae cell viability during fermentation in different substrates: (A) — hydrolysate HA (3\% PSB 24

h); • hydrolysate HD (10\% PSB 72 h); (B) hydrolysate HD (匹 pre-inoculum 1DO; • pre-inoculum 24 h).

\subsection{Ethanol production}

The compounds produced after fermentations are presented in Table 2. After the fermentation of hydrolysate HD, S. cerevisiae produced $16.15 \mathrm{~g} / \mathrm{L}$ of ethanol, with a Qp of $0.67 \mathrm{~g} / \mathrm{Lh}$, and $Y_{p / s}$ of $0.48 g_{\text {ethanol }} / g_{\text {sugar, }}$ demonstrating great ethanol yields. Previous studies have evaluated the enhancement of the ethanol titre after the fermentations of hydrolysates of pre-treated sugarcane bagasse. The found ethanol concentration was higher than the reported values in some earlier works. Pereira et al. (2016) obtained $3.15 \mathrm{~g} / \mathrm{L}$ of ethanol after fermentation with $S$. cerevisiae of $10 \%$ ozonolysis pre-treated SCB hydrolysate. Travaini, Barrado, \& Bolado-Rodríguez, (2016) obtained $7.19 \mathrm{~g} / \mathrm{L}$ of ethanol after fermentation with $\mathrm{S}$. cerevisiae of $6 \%$ ozonolysis pretreated SCB, submitted to saccharification with Celluclast $1.5 \mathrm{~L}$ and Novozym 188 (10 FPU/30 CBU/g 
cellulose). Martín et al. (2002) produced $8.2 \mathrm{~g} / \mathrm{L}$ of ethanol after fermentation by S. cerevisiae of hydrolysate containing $10 \%$ steam exploded pre-treated SCB, with a $Q_{p}$ of $0.65 \mathrm{~g} / \mathrm{Lh}$. Wanderley et al. (2013) fermented hydrolysate of $8 \%$ of steam exploded PSB, submitted to hydrolysis (10 FPU/g of Celluclast $1.5 \mathrm{~L}$ and Novozym 188) and obtained close values $\left(16.75 \mathrm{~g} / \mathrm{L}\right.$ of ethanol and $\mathrm{Q}_{p}$ of 0,25 g/Lh) to the current study. Santos, Souto-Maior, Gouveia, \& Martín, (2010) submitted 8\% of $\mathrm{NaOH}$ delignified SCB to hydrolysis with $30 \mathrm{FPU}$ and $20 \mathrm{CBU} / \mathrm{g}$ of bagasse (Celluclast and Novozym 188) and obtained a maximum $Q_{p}$ of $0.25 \mathrm{~g} / \mathrm{Lh}$ after fermentation of this hydrolysate. Moreover, Singh, Sharma, Saran, Singh, \& Bishnoi, (2013) also fermented hydrolysate of $\mathrm{NaOH}$ delignified SCB submitted to hydrolysis with Aspergillus flavus enzymatic extract and obtained $15.4 \mathrm{~g} / \mathrm{L}$ of ethanol, with $Q_{p}$ of $0.43 \mathrm{~g} / \mathrm{Lh}$, and $\mathrm{Y}_{\mathrm{P} / \mathrm{s}}$ of $0.44 \mathrm{~g}_{\text {ethanol }} / \mathrm{g}_{\text {sugar. }}$ (Wang et al., 2016) obtained a comparable ethanol concentration $(17 \mathrm{~g} / \mathrm{L}$ ) after fermentation of hydrolysate of $5 \%$ PSB containing $61.0 \mathrm{~g} / \mathrm{L}$ of glucose. Jiang et al. (2017) fermented hydrolysate of $\mathrm{Na}_{2} \mathrm{SO}_{3} / \mathrm{Na}_{3} \mathrm{PO}_{4}$ pre-treated $\mathrm{SCB}$ with $S$. cerevisiae and achieved $\mathrm{Y} / \mathrm{s}$ of 0.42 gethanol/gglucose.

Besides bioethanol, other compounds were produced in non-significant amounts after fermentation, such as acetic acid and galacturonic acid. The low acetic acid concentration achieved is relevant since its toxic effects can cause the reduction of yeast growth and fermentation inhibition (Oliva-Neto, Dorta, Azevedo, Gomes, \& Fernandes, 2013). Therefore, the low inhibitor concentrations observed after fermentation resulted in remarkable conversion of sugars into ethanol.

Table 2: Compounds produced by S. cerevisiae after fermentations of PSB hydrolysates, ethanol yield rates ( $\mathrm{Y}_{\mathrm{P} / \mathrm{S}}$ ) and volumetric productivity $\left(Q_{P}\right)$.

\begin{tabular}{c|c|c}
\hline Compounds & \multicolumn{2}{|c}{ Hydrolysate } \\
\cline { 2 - 3 }$(\mathrm{g} / \mathrm{L})$ & $\mathrm{HA}$ & $\mathrm{HD}$ \\
\hline Ethanol & $1.42 \pm 0.24$ & $16.15 \pm 0.00$ \\
Galacturonic Acid & $0.20 \pm 0.00$ & $0.65 \pm 0.04$ \\
Acetic Acid & $\mathrm{ND}$ & $0.98 \pm 0.18$ \\
\hline $\mathrm{Y}_{\mathrm{P} / \mathrm{s}}\left(\mathrm{g}_{\text {ethanol }} / \mathrm{g}_{\text {sugar }}\right)$ & 0.15 & 0.48 \\
$\mathrm{Q}_{\mathrm{p}}(\mathrm{g} / \mathrm{Lh})$ & 0.06 & 0.67 \\
\hline
\end{tabular}

*ND - below the limit of detection.

The different concentrations of sugars in the hydrolysates and their respective consumption (\%) after alcoholic fermentation were compared in Table 3. The data demonstrated that S. cerevisiae was able to completely ferment the glucose in hydrolysate HD, with $99.96 \%$ of consumption of this sugar. These results clearly indicated that the increase of the percentage of dry substrate to $10 \%$ of PSB in hydrolysis HD led to a significant increase in the sugar release with the consequent total bioconversion of glucose to ethanol. This trend was also reported by Raj and Krishnan (2019), who obtained high concentrations of glucose after hydrolysis of sugarcane bagasse with increased solid loading and subsequent enhancement in the production of bioethanol from the fermentation of hydrolysates. 
Table 3: Sugar concentrations $(\mathrm{g} / \mathrm{L}$ ) before and after the alcoholic fermentation of PTA hydrolysates.

\begin{tabular}{c|c|c|c|c|c|c}
\hline \multirow{2}{*}{ Sugars } & \multicolumn{4}{|c|}{ HA } & \multicolumn{3}{c}{ HD } \\
\cline { 2 - 7 } & $\begin{array}{c}\text { Hydrolysate } \\
(\mathrm{g} / \mathrm{L})^{*}\end{array}$ & $\begin{array}{c}\text { Fermentation } \\
(\mathrm{g} / \mathrm{L})^{*}\end{array}$ & $\begin{array}{c}\text { Consume } \\
(\%)\end{array}$ & $\begin{array}{c}\text { Hydrolysate } \\
(\mathrm{g} / \mathrm{L})^{*}\end{array}$ & $\begin{array}{c}\text { Fermentation } \\
(\mathrm{g} / \mathrm{L})^{*}\end{array}$ & $\begin{array}{c}\text { Consume } \\
(\%)\end{array}$ \\
\hline Glucose & $9.88 \pm 0.24$ & $1.91 \pm 0.73$ & 80.62 & $28.60 \pm 2.30$ & $0.01 \pm 0.17$ & 99.96 \\
Xylose & $4.62 \pm 0.06$ & $4.60 \pm 0.04$ & 0.56 & $9.88 \pm 0.90$ & $9.85 \pm 0.66$ & 0.30 \\
\hline
\end{tabular}

* The concentrations of sugars refer to the initial time of the fermentation after the dilution of the hydrolysate with addition of $10 \%$ of inoculum (v/v).

\section{CONCLUSIONS}

To achieve high yields of $2 \mathrm{G}$ bioethanol, is necessary the release of elevated concentrations of sugars after enzymatic hydrolysis of cellulosic biomass. This study showed that the highest concentrations of TRS $(73.96 \mathrm{~g} / \mathrm{L})$ and glucose $(31.78 \mathrm{~g} / \mathrm{L})$ were obtained after the enzymatic saccharification carried out with the highest solid load (10\% alkaline pre-treated sugarcane bagasse during $72 \mathrm{~h}$ - hydrolysis HD). Furthermore, the presence of inhibitors was not detected in the hydrolysates, contributing positively to the fermentative process. The maximum ethanol yield was also achieved after the fermentation of hydrolysate $H D$, with the highest values of $Y_{p / s}, Q_{p}$ and entire consumption of hexose (99.96\%). These results reinforce that the increase in solid substrate load (percentage of PSB) in the hydrolysis can positively influence the amount of released sugars in the hydrolysate and consequently improve the production of bioethanol. On the other hand, this study demonstrated that the factor time was not a crucial factor for the improvement enzymatic hydrolysis. The data showed that the alkaline pre-treated PSB has good potential for the cellulose saccharification and further enhancement of cellulosic ethanol production. Future studies of PSB hydrolysis with higher substrate loads might be conducted in order to promote still more expressive sugar and ethanol yields.

\section{ACKNOWLEDGEMENTS}

The authors thank to Uberlândia Federal University (UFU) for the technical support.

\section{DISCLOSURE OF POTENTIAL CONFLICTS OF INTEREST}

The authors declared no conflicts of interest with respect to the research, authorship and/or publication of this article. 


\section{FUNDING}

This study received financial support from the Minas Gerais State Research Funding Agency (FAPEMIG grant number APQ-01360-14).

\section{RESEARCH INVOLVING HUMAN PARTICIPANTS AND/OR ANIMALS}

Not applicable.

\section{INFORMED CONSENT}

Informed consent was obtained from all individual participants included in the study.

\section{AUTHOR CONTRIBUTIONS}

K.F.R. Lamounier designed and performed the experiments, analyzed the data and wrote the manuscript. P.O. Rodrigues and A.S. Santos contributed to perform the experiments. D. Pasquini contributed with funding support and analysis of the data. M.A. Baffi supervised the design and development of research, the analysis of the data and the writing of the manuscript. All authors have approved the final manuscript.

\section{REFERENCES}

Antil, P. S., Gupta, R., \& Kuhad, R. C. (2014). Simultaneous saccharification and fermentation of pretreated sugarcane bagasse to ethanol using a new thermotolerant yeast. Annals of Microbiology, 65(1), 423-429. https://doi.org/10.1007/s13213-014-0875-2

Brito, P. L., Ferreira, C. M. de A., Silva, A. F. F., Pantoja, L. D. A., Nelson, D. L., \& Dos Santos, A. S. (2017). Hydrolysis, detoxification and alcoholic fermentation of hemicellulose fraction from palm press fiber. Waste and Biomass Valorization, $0(0), 1-12$. https://doi.org/10.1007/s12649-017-9882-4

de Andrade, L. G. A., Maitan-Alfenas, G. P., Morgan, T., Gomes, K. S., Falkoski, D. L., Alfenas, R. F., \& Guimarães, V. M. (2017). Sugarcane bagasse saccharification by purified $\beta$-glucosidases from Chrysoporthe cubensis. Biocatalysis and Agricultural Biotechnology, 12, 199-205. https://doi.org/10.1016/j.bcab.2017.10.007

de Sousa Gomes, K., Maitan-Alfenas, G. P., de Andrade, L. G. A., Falkoski, D. L., Guimarães, V. M., Alfenas, A. C., \& de Rezende, S. T. (2017). Purification and Characterization of Xylanases from the Fungus Chrysoporthe cubensis for Production of Xylooligosaccharides and Fermentable Sugars. Applied Biochemistry and Biotechnology, 182(2), 818-830. https://doi.org/10.1007/s12010-016-2364-5

Ghose, T. K. (1987). Measurment of cellilase activities. Pure and Applied Chemistry, 59(2), 257-268. https://doi.org/https://doi.org/10.1351/pac198759020257 
Guerrero, A. B., Ballesteros, I., \& Ballesteros, M. (2018). The potential of agricultural banana waste for bioethanol production. Fuel, 213(April 2017), 176-185. https://doi.org/10.1016/j.fuel.2017.10.105

Huang, Q., Yan, Q., Fu, J., Lv, X., Xiong, C., Lin, J., \& Liu, Z. (2016). Comparative study of different alcoholate pretreatments for enhanced enzymatic hydrolysis of sugarcane bagasse. Bioresource Technology, 211, 464-471. https://doi.org/10.1016/j.biortech.2016.03.067

Jiang, C. X., He, Y. C., Chong, G. G., Di, J. H., Tang, Y. J., \& Ma, C. L. (2017). Enzymatic in situ saccharification of sugarcane bagasse pretreated with low loading of alkalic salts $\mathrm{Na}_{2} \mathrm{SO}_{3} / \mathrm{Na}_{3} \mathrm{PO}_{4}$ by autoclaving. Journal of Biotechnology, 259, 73-82. https://doi.org/10.1016/j.jbiotec.2017.08.004

Martín, C., Galbe, M., Wahlbom, C. F., Hahn-Hägerdal, B., \& Jönsson, L. J. (2002). Ethanol production from enzymatic hydrolysates of sugarcane bagasse using recombinant xyloseutilising Saccharomyces cerevisiae. Enzyme and Microbial Technology, 31, 274-282.

Miller, G. L. (1959). Use of dinitrosalicylic acid reagent for determination of reducing sugar. Analytical Chemistry, 31(3), 426-428. https://doi.org/10.1021/ac60147a030

Moreira, F. S., Machado, R. G., Romão, B. B., Batista, F. R. X., Ferreira, J. S., \& Cardoso, V. L. (2017). Improvement of hydrogen production by biological route using repeated batch cycles. Process Biochemistry, 58, 60-68. https://doi.org/10.1016/j.procbio.2017.04.013

Nascimento, V. M., Manrich, A., Tardioli, P. W., de Campos Giordano, R., de Moraes Rocha, G. J., \& Giordano, R. de L. C. (2016). Alkaline pretreatment for practicable production of ethanol and xylooligosaccharides. Bioethanol, 2(1), 112-125. https://doi.org/10.1515/bioeth-2016-0008

Nouri, H., Azin, M., \& Mousavi, M. L. (2017). Xylan-hydrolyzing thermotolerant Candida tropicalis HNMA-1 for bioethanol production from sugarcane bagasse hydrolysate. Annals of Microbiology, 67(9), 633-641. https://doi.org/10.1007/s13213-017-1292-0

Oliva-Neto, P. De, Dorta, C., Azevedo, F., Gomes, V., \& Fernandes, D. (2013). The Brazilian technology of fuel ethanol fermentation - yeast inhibition factors and new perspectives to improve the technology. Formatex, 371-379.

Pathania, S., Sharma, N., \& Handa, S. (2017). Immobilization of co-culture of Saccharomyces cerevisiae and Scheffersomyces stipitis in sodium alginate for bioethanol production using hydrolysate of apple pomace under separate hydrolysis and fermentation. Biocatalysis and Biotransformation, 35(6), 450-459. https://doi.org/10.1080/10242422.2017.1368497

Pereira, J. de C., Travaini, R., Paganini Marques, N., Bolado-Rodríguez, S., \& Bocchini Martins, D. A. (2016). Saccharification of ozonated sugarcane bagasse using enzymes from Myceliophthora thermophila JCP 1-4 for sugars release and ethanol production. Bioresource Technology, 204, 122-129. https://doi.org/10.1016/j.biortech.2015.12.064

Petrou, E. C., \& Pappis, C. P. (2009). Biofuels: a survey on pros and cons. Energy and Fuels, 23(2), 1055-1066. https://doi.org/10.1021/ef800806g 
Raj, K.; Krishnan, C. (2019). Improved high solid loading enzymatic hydrolysis of low-temperature aqueous ammonia soaked sugarcane bagasse using laccase-mediator system and high concentration ethanol production. Industrial Crops and Products, 131, 32-40. https://doi.org/10.1016/j.indcrop.2019.01.032

Rodrigues, P. de O., Pereira, J. de C., Santos, D. Q. dos, Gurgel, L. V. A., Pasquini, D., \& Baffi, M. A. (2017). Synergistic action of an Aspergillus (hemi-) cellulolytic consortium on sugarcane bagasse saccharification. Industrial Crops and Products, 109, 173-181. https://doi.org/10.1016/j.indcrop.2017.08.031

Sahu, S., \& Pramanik, K. (2018). Evaluation and optimization of organic acid pretreatment of cotton gin waste for enzymatic hydrolysis and bioethanol production. Applied Biochemistry and Biotechnology, 186(4), 1047-1060. https://doi.org/10.1007/s12010-018-2790-7

Santos, J. R. A. dos, Souto-Maior, A. M., Gouveia, E. R., \& Martín, C. (2010). Comparison of SHF and SSF processes from sugarcane bagasse for ethanol production by Saccharomyces cerevisiae. Quimica Nova, 33(4), 904-908.

Saratale, G. D., Saratale, R. G., Kim, S. H., \& Kumar, G. (2018). Screening and optimization of pretreatments in the preparation of sugarcane bagasse feedstock for biohydrogen production and process optimization. International Journal of Hydrogen Energy, 43(25), 11470-11483. https://doi.org/10.1016/j.ijhydene.2018.01.187

Silva, T. A. L., Zamora, H. D. Z., Varão, L. H. R., Prado, N. S., Baffi, M. A., \& Pasquini, D. (2017). Effect of steam explosion pretreatment catalysed by organic acid and alkali on chemical and structural properties and enzymatic hydrolysis of sugarcane bagasse. Waste and Biomass Valorization, 0(0), 1-11. https://doi.org/10.1007/s12649-017-9989-7

Singh, A., Sharma, P., Saran, A. K., Singh, N., \& Bishnoi, N. R. (2013). Comparative study on ethanol production from pretreated sugarcane bagasse using immobilized Saccharomyces cerevisiae on various matrices. Renewable Energy, 50, 488-493. https://doi.org/10.1016/j.renene.2012.07.003

Travaini, R., Barrado, E., \& Bolado-Rodríguez, S. (2016). Effect of ozonolysis parameters on generation of inhibitory compounds and on production of ethanol by Pichia Stipitis and Acetona-Butanol-Ethanol by Clostridium from ozonated and water washed sugarcane bagasse. Bioresource In Technology, press., doi: http://dx.doi.org/10.1016/j.biortech.2016.07. https://doi.org/10.1016/j.biortech.2016.07.028

Valinhas, R. V., Pantoja, L. A., Maia, A. C. F., Miguel, M. G. C. P., Vanzela, A. P. F. C., Nelson, D. L., \& Santos, A. S. (2018). Xylose fermentation to ethanol by new Galactomyces geotrichum and Candida akabanensis strains. PeerJ, 6, e4673. https://doi.org/10.7717/peerj.4673

Wanderley, M. C. de A., Martín, C., Rocha, G. J. de M., \& Gouveia, E. R. (2013). Increase in ethanol production from sugarcane bagasse based on combined pretreatments and fed-batch enzymatic hydrolysis. Bioresource Technology, 128, 448-453. https://doi.org/10.1016/j.biortech.2012.10.131 
Wang, W., Wang, Q., Tan, X., Qi, W., Yu, Q., Zhou, G., Zhuang, X., \& Yuan, Z. (2016). High conversion of sugarcane bagasse into monosaccharides based on sodium hydroxide pretreatment at low water consumption and wastewater generation. Bioresource Technology, 218, 1230-1236. https://doi.org/10.1016/j.biortech.2016.07.074

\section{COMO CITAR ESTE ARTIGO:}

Lamounier, K. F., Rodrigues, P. O., Pasquini, D., Soares, A. S, Baffi, M. A. (2020). Effects of the increase in substrate load and hydrolysis time in the saccharification of sugarcane bagasse and ethanol production . Holos. 36(6), 1-14.

\section{SOBRE OS AUTORES}

\section{K. F. LAMOUNIER}

Engenheira Ambiental.Pós-Graduação em Biocombustíveis. E-mail: kkeninhala@yahoo.com.br ORCID ID: https://orcid.org/0000-0003-2536-9288

\section{P. O. RODRIGUES}

Bióloga. Pós-Graduação em Biocombustíveis. E-mail: patrisia.rodrigues@ufu.br

ORCID ID: https://orcid.org/0000-0002-3052-7503

\section{D.PASQUINI}

Químico. Instituto de Química. Pós-Graduação em Biocombustíveis. E-mail: danielpasquini@ufu.br ORCID ID: http://orcid.org/0000-0001-7441-5143

\section{A. S. SOARES}

Farmacêutico. Pós-Graduação em Biocombustíveis. E-mail: alexandre.soares@ufvjm.edu.br ORCID ID: http://orcid.org/0000-0003-2417-8084

\section{A. BAFFI}

Bióloga. Instituto de Ciências Agrárias. Pós-Graduação em Biocombustíveis. E-mail: milla.baffi@ ufu.br ORCID ID: http://orcid.org/0000-0003-0983-889X

Editor(a) Responsável: Francinaide de Lima Silva Nascimento

Pareceristas Ad Hoc: LEANDRO CORREIA E RODRIGO SILVA

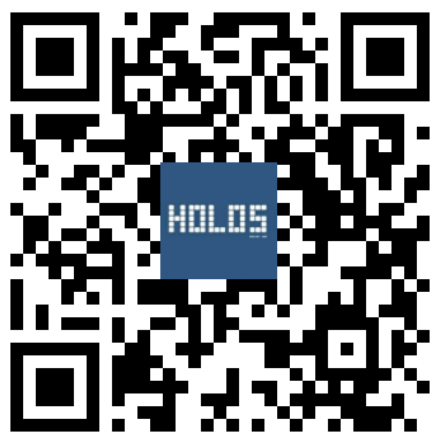

